\title{
Application of Lean Production/Construction to Reduce Waste in Pipe Gas Construction (Case Study of Semare-Tie in KM 19 Pipa Porong Grati Gas Development Project PT Pertamina Gas)
}

\author{
Taufik Widayat $^{1}$ and Bambang Syairudin ${ }^{2}$
}

\begin{abstract}
The lean approach, which was initially used in manufacturing industry, now is widely adopted by the construction industry called lean construction, in order to reduce waste and to optimize the value. This study was conducted to see the suitability of the lean construction approach on the EPC project of gas pipeline installation. This study is viewed from the Company side as the owner particularly in engineering aspect which is carried out by the company itself. Engineering work is deemed as a key to the next activity which is effective and efficient procurement and construction phase. Almost all similar projects show the same symptoms such as: low quality of engineering work (amendment value above 10\%), target and realization lagging of its progress, re-work, weak coordination and residual materials. Therefore, the urgency to make improvements occur with the Lean Construction approach described in Big Picture Mapping, Value Stream Analysis Tool, Pareto Diagram, Fishbone Diagram at each stage of the engineering work EPC gas pipeline. Value Added (VA) activities were obtained at $39.35 \%$ and Non-Added Value (NVA) activities at $60.65 \%$, engineering work quality classified as poor (amendment value 12.81\%). The application of a lean construction approach is suitable to be applied in Company for gas pipe installation projects but with some notes. Then a comprehensive evaluation is required to evaluate man power, load, and skills needed and eventually to be standardized in an acknowledged company standard in order to make every project to be done punctually. The dominant root cause of the problem is the engineering contract form (a lump-sum engineering contract) and company policy as the reference to identify the contract form itself.
\end{abstract}

Keywords-Waste, Lean Construction, Big Picture Mapping, Fishbone Diagram, Value Added (VA), Non Value Added (NVA).

\section{INTRODUCTION}

One of the Pertagas's strategic program in improving infrastructure and open access pipeline connectivity is construction of the $8 \mathrm{Km} \varnothing 18$-inch transmission pipeline

\footnotetext{
${ }^{1}$ Taufik Widayat is with Department of Business Management, Institut Teknologi Sepuluh Nopember, Surabaya, 60231, Indonesia. E-mail: widayat.taufik@yahoo.com.

${ }^{2}$ Bambang Syairudin is with Department of Industrial Engineering, Institut Teknologi Sepuluh Nopember, Surabaya, 60231, Indonesia. Email: bambangsyairudin@gmail.com.
}

from Semare through junction KM 19 Porong-Grati gas pipe line to flow gas from BD field off Madura landed in ORF Semare operated by CNOOC Madura Husky Ltd. (HCML) towards the Porong-Grati open access pipeline.

Every construction project must be well planned, resources, scheduling work implementation, method, specifications \& quality control, monitoring and project control. Even so, not all activities in the project will provide maximum value or added value, because of the variety and quantity of project work is very complex and interconnected each other and involving many stakeholders. Waste or non-added value activity is work that does not provide added value and unnecessary action in the process [1]. The construction project progress does not work according to schedule because there are many activities that do not add value, such as: waiting for material arrival, waiting for work instructions, defects in pipe material, etc. Therefore, companies need to take the right steps to identifying and eliminating waste to prevent delays and customer's satisfaction. In Pertagas's EPC project it is typical there are some work carried out by the company itself, such as the management of permits \& outreach to regional government level I-II, management of environmental documents, and engineering work to review detailed engineering design submitted by the contractor.

Infrastructure project usually put time as main target that has to be fulfilled [2]. One of main characteristic of a project is doing something that has never been done before, or can be said that each project is unique [2]. Typical symptom waste occurs in project are over due date, design change and addition, budget overrun. For that's reason, a lean approach is needed especially in engineering works which carried out by company itself from time to time and as key to effective-efficient procurement or construction could be done. The scope in this lean approach is seen from the perspective of the project owner (owner) not the contractor or project executor, in engineering work only. 


\section{LITERATURE REVIEW}

\section{A. Lean Construction Approach in Engineering Work}

Lean can be defined as a systematic and systematic approach to eliminate waste or non-value-adding activities through radical continuous improvement by flowing products (material, work-in-process, output) and information using a pull system from internal and external customers to pursue excellence and perfection [3]. Lean construction is a way to design a production system that can minimize waste from material usage, time and effort in order to produce the maximum amount of value[4], [5]. Table 1 shows approximately data waste occur in construction and its consequences [6].

The lean construction approach starts with determining the types of waste, describing the whole stream across project activity and selecting the right tools to get the relationship between waste and the mapping tool used, identifying the waste that occurs as well as tools that can be used to eliminate waste, analysing waste-causing activities to find the dominant causes, finding root causes of waste. Furthermore, risk management can be carried out against the existing risks and finally a conclusion can be drawn and continued with recommendations.

\section{B. Determining Type of Waste}

Shigeo Shingo has been identified 7 (seven) waste, there are[7]:

1. Overproduction, producing too much or too fast, resulting in a bad flow of goods / information and resulting excess inventory, caused by long set-up or lead times.

2. Waiting, periods are caused by the ineffectiveness of workers, information, or goods, causing poor flow and long lead times. It is an interval in the value adding process.

3. Transportation, excessive movement of workers, information, and goods that wastes time and resources, ie. carrying items that are still in the process in a long distance, inefficient transportation, or moving material, components, or parts into and out of buildings or between processes, thus increasing the time needed to handle material.

4. Processing, work processes occur using the wrong set of devices, procedures, or systems. This is for example when the work method or process is done inappropriately by carrying out activities that should not be necessary so that it can increase production costs. This can also occur due to non-standard processes that allow variations to occur.

5. Inventory, in this case the most visible is the presence of excess inventory, can be in the form of raw materials, work in process, and finished products. With excess inventory, it must have an effect on the increase in storage costs.

6. Motion, poor working environment has resulted in work becoming more difficult than it should be, as is the movement that should not be carried out by workers, and does not provide added value, for example workers must be pacing in an area, having to squat and so on. This can be caused by poor layout.

7. Defect, is the result of a production process that is not in line with expectations, such as damaged product, not in accordance with specifications, generally related to quality problems. This is will cause waste because it requires repetitive work and extra expenses to replace/rework the product.

\section{Methodology}

Figure 1 shows how the research will be, its start with set up the research topic and object, problems identification, research goal set up, literature and field study, determining the whole streams, waste identification and rank, analyzing and interpreting data, root caused analyzing, conclusion, suggestion and recommendation.

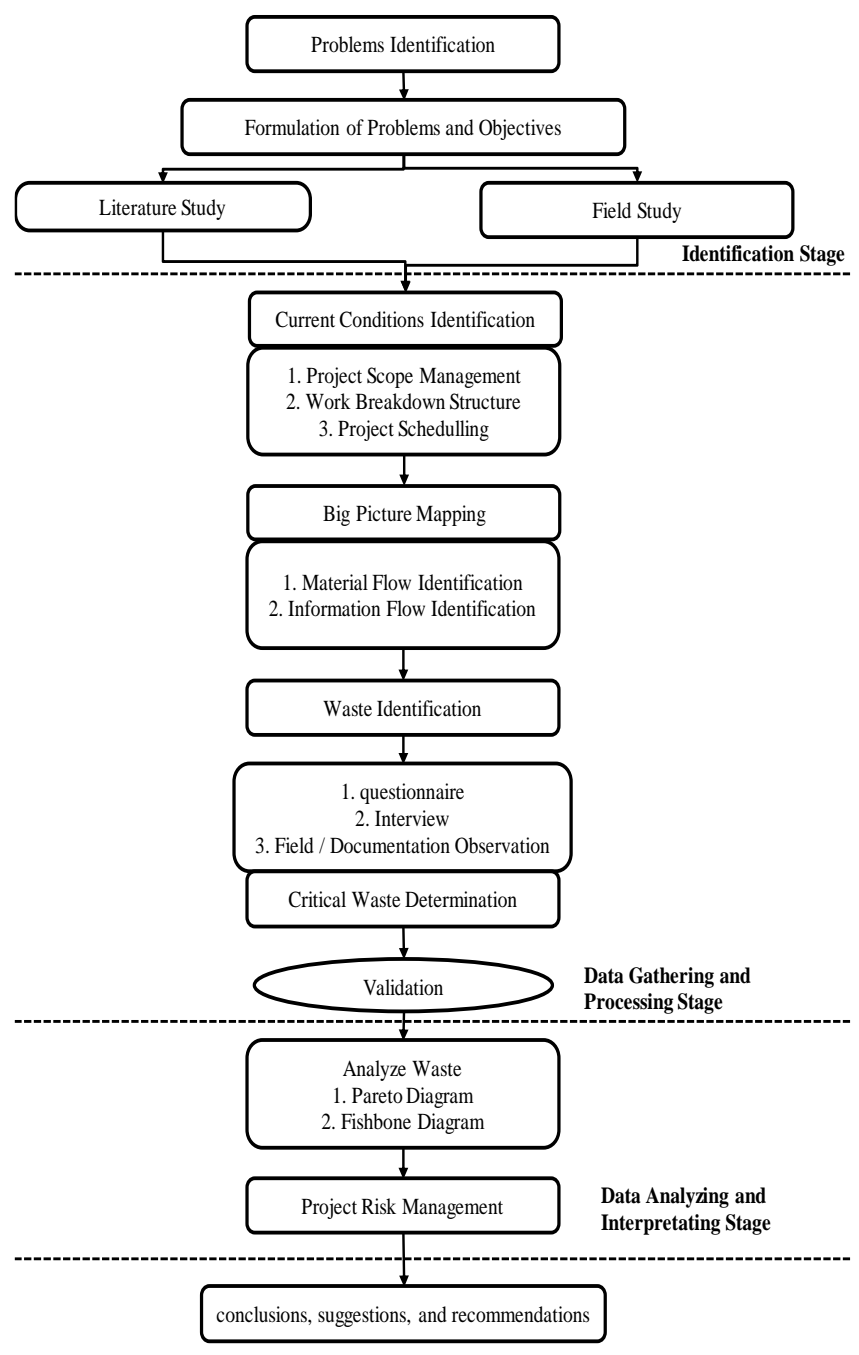

Figure 1. Research Methodology Scheme 
The $1^{\text {st }}$ International Conference on Business and Management of Technology (IConBMT)

August 3rd 2019, Institut Teknologi Sepuluh Nopember, Surabaya, Indonesia

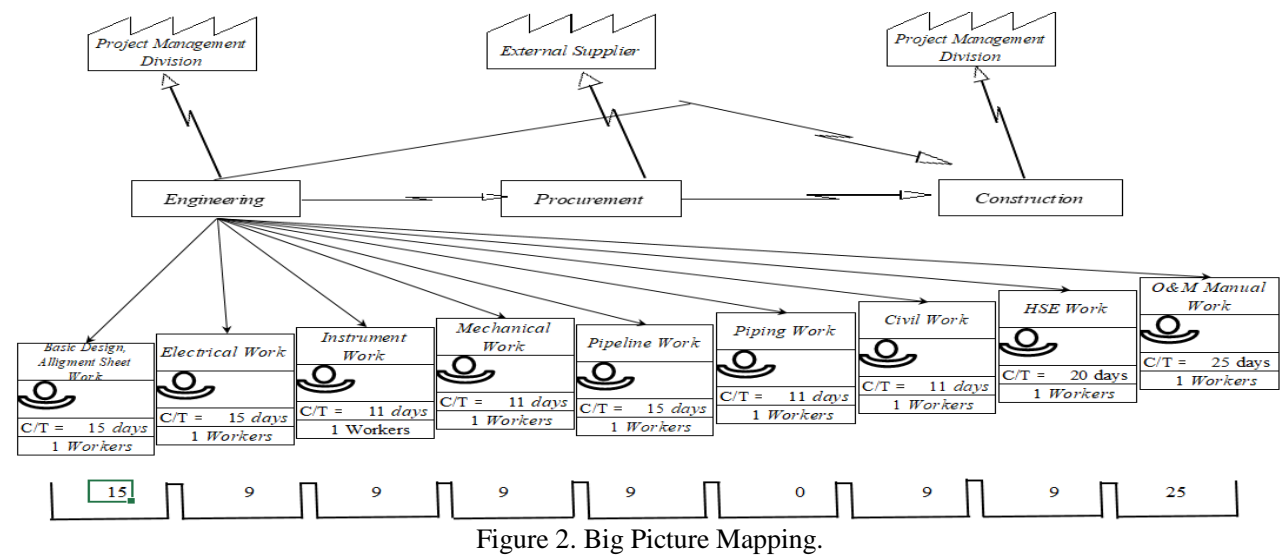

\section{RESULT AND DISCUSSION}

\section{A. Determining The Whole Stream}

In this study the Big Picture Mapping (BPM) is use to depicting the whole stream across project activity. Whole streams identification is processed from various data such as:

1. Literature study, project master schedule, and others information sources.

2. Discussion with respondents directly involved in engineering project management team.

3. Field observation regarding geographical and demographic condition of the project

Through BPM as seen in Figure 2 we get a comprehensive known which areas have the potential for waste. Furthermore, it can be seen that engineering activities included in the VA have a total time of 94 days, meanwhile from the PMS (Project Master Schedule) it is known that the total project end to end is 94 days. It's means that there's not only no room for NVA activities in engineering work, but also for other activities, so that the schedule is very challenging, tight and must be done in parallel. These activities have the potential to cause delays in the execution of this project

\section{B. Waste Identification and Rank}

Done with questionnaires to personnel involved in project management team, aims to find out the ranking of the seven wastes that occurred in the project as shown in Table 2.

TABLE 2 .

WASTE SCORE

\begin{tabular}{lll}
\hline \multicolumn{3}{c}{ WASTE SCORE } \\
\hline No & \multicolumn{1}{c}{ Waste } & Score \\
\hline 1 & Unnecessary Motion & 3.750 \\
2 & Waiting & 3.203 \\
3 & Inappropriate Processing & 3.094 \\
4 & Over Production & 2.875 \\
5 & Excessive Transportation & 2.844 \\
6 & Defect & 2.500 \\
7 & Unnecessary Inventory & 2.047 \\
\hline \hline
\end{tabular}

C. Waste Analysis Using VALSAT

TABLE 3.

VALUE STREAM ANALYSIS TOOL SCORE

\begin{tabular}{cll}
\hline \hline No & Value Stream Mapping Tools & Score \\
\hline 1 & Process Activity Mapping & 127.53 \\
2 & Supply Chain Response Matrix & 59.63 \\
3 & Production Variety Tunnel & 18.63 \\
4 & Quality Filter Mapping & 5.97 \\
5 & Demand Amplification Mapping & 36.66 \\
6 & Decision Point Analysis & 27.47 \\
7 & Physical Structure Mapping & 6.59 \\
\hline \hline
\end{tabular}

Analysis only conducted on engineering works that done by the company itself. Three tools with the highest value were chosen then analysis carried out only in engineering works as shown in Table 3.

\section{1) Demand Amplification Mapping}

Usually happens to companies that produce consumer goods, in this case it can be seen that inventory owned by engineering task forces can be deemed engineering to order company (ETO) type, so that it does not allow a bullwhip effect to occur in its distribution network. Documents that do not get the AFC status can still be used, but the possibility is very small, because each contract of work usually has different types and specifications.

2) Supply Chain Response Matrix (SCRM)

a. First stage, deliverables document are 181 pcs. If the engineering lead time is 28 days, in average the contractor engineering team can submit 7 docs, the engineering task force.

b. Second stage, in the engineering section, the engineering task force team has an average output of 4 engineering docs per day, the length of time needed to complete the overall deliverables engineering is 71.75 days

Then it can be concluded that the time needed to complete the entire engineering document exceeds the available time, so a comprehensive evaluation of the man power requirements, load, and needed skill is needed in order the project can be on time. 
The $1^{\text {st }}$ International Conference on Business and Management of Technology (IConBMT)

August 3rd 2019, Institut Teknologi Sepuluh Nopember, Surabaya, Indonesia

3) Process Activity Mapping (PAM)

See Table 4 below for the VA and NVA calculation.

TABLE 4.

\begin{tabular}{clcl}
\multicolumn{4}{c}{ VA AND NVA ACTIVITY CALCULATION } \\
\hline \hline No. & \multicolumn{1}{c}{ Activity } & Total Time & \multicolumn{1}{c}{$\%$} \\
\hline 1 & Operation (O) & 94 & 60.65 \\
2 & Transportation (T) & 0 & 0.00 \\
3 & Inspection (I) & 36 & 23.23 \\
4 & Storage (S) & 25 & 16.13 \\
5 & Delay (D) & 0 & 0.00 \\
\hline \hline
\end{tabular}

\section{Root Caused Analysis and Proposed Improvement}

Waste analysis and proposed improvements are carried out only on waste related to engineering works, because only those fields are carried out by the company itself and to prevent occurrence of the other waste in other process which use the output of engineering (procurement and the construction process). A project engineering document grade can be approached based on the value of the amendment of the work, a brainstorming approach with expert in company as shown in Table 5 Project Engineering Documents Grade Based on Amendment Values.

To resolving the problem, a pareto diagram of waste type is created from the list of problems to find out the most frequently problem occurs as shown in Figure 3.

Combining the impact value of each existing risk list, a pareto table can be made to find out the most significant risk for improvement as shown in Table 6 Seven Waste Pareto Rank, a comprehensive evaluation in five aspect (man, material, methode, machine, and environment) to find the root cause of the dominant risk using a Fishbone Diagram as shown in Figure 4. VA and NVA Activity Calculation.

TABLE 6 . SEVEN WASTE PARETO RANK

\begin{tabular}{|c|c|c|c|c|c|c|}
\hline \multirow{2}{*}{ No } & \multirow{2}{*}{ Waste } & Freq. & Effect & Freq. $x$ Effect & $\%$ & \multirow{2}{*}{$\begin{array}{l}\text { Pareto } \\
\text { Rank }\end{array}$} \\
\hline & & $\mathrm{a}_{\mathrm{i}}$ & $b_{i}$ & $c_{i}=a_{i} \times b_{i}$ & $\mathrm{~d}_{\mathrm{i}}=\mathrm{c}_{\mathrm{i}} / \sum \mathrm{c}$ & \\
\hline 1 & Defect & 2.50 & 3.41 & 8.52 & 11.32 & 6 \\
\hline 2 & Waiting & 3.20 & 3.81 & 12.19 & 16.21 & 2 \\
\hline 3 & $\begin{array}{l}\text { Over } \\
\text { production }\end{array}$ & 2.88 & 3.63 & 10.42 & 13.85 & 4 \\
\hline 4 & $\begin{array}{l}\text { In-Appropriate } \\
\text { Process }\end{array}$ & 3.09 & 3.88 & 11.99 & 15.94 & 3 \\
\hline 5 & $\begin{array}{l}\text { Excessive } \\
\text { Transportation }\end{array}$ & 2.84 & 3.50 & 9.95 & 13.23 & 5 \\
\hline 6 & $\begin{array}{l}\text { Unnecessary } \\
\text { Inventory }\end{array}$ & 2.05 & 3.34 & 6.84 & 9.10 & 7 \\
\hline 7 & $\begin{array}{l}\text { Unnecessary } \\
\text { Motion }\end{array}$ & 3.75 & 4.08 & 15.31 & 20.35 & 1 \\
\hline & Total & & & 75.23 & 100.00 & \\
\hline
\end{tabular}

\section{7-Waste}

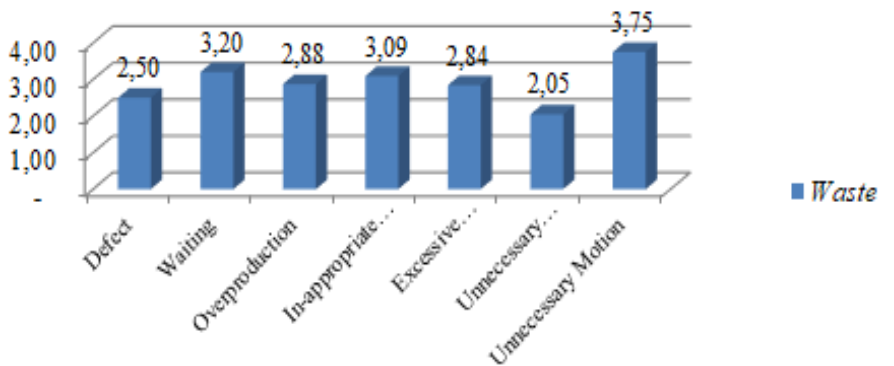

Figure 3. Frequency of The Seven Waste

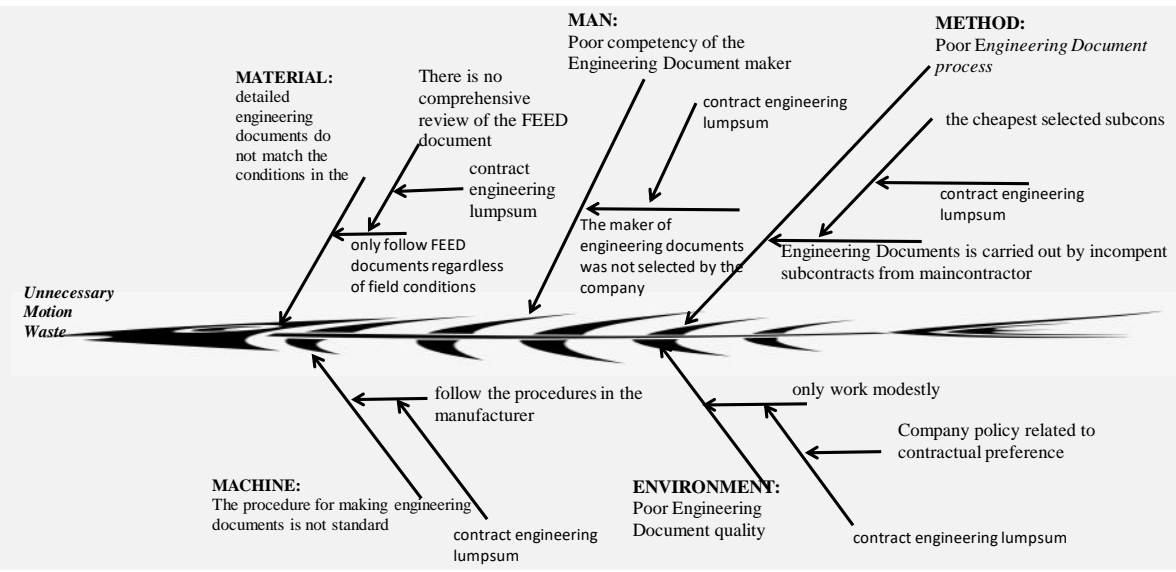

Figure 4. Root Caused Analysis: Fishbone Diagram. 
The $1^{\text {st }}$ International Conference on Business and Management of Technology (IConBMT)

August 3rd 2019, Institut Teknologi Sepuluh Nopember, Surabaya, Indonesia

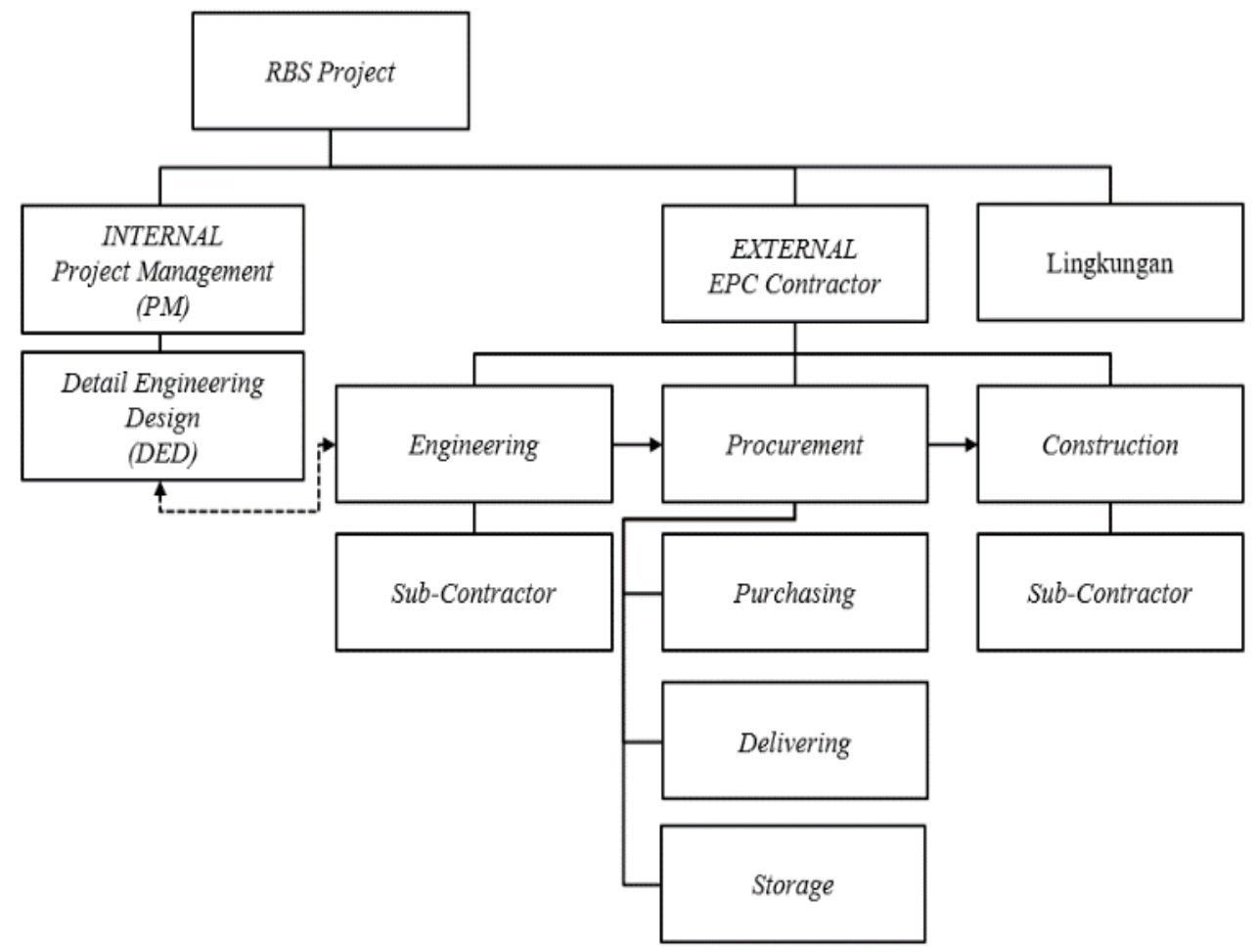

Figure 5. Risk Breakdown Structure to Critical Waste

TABLE 7.

Waste ASPeCts, PRoBlems AND RoOT CAUSE

\begin{tabular}{clll}
\hline \hline No & Waste Aspect & \multicolumn{1}{c}{ Problem } & \multicolumn{1}{c}{ Root Cause } \\
\hline 1 & Material & detailed engineering documents do not match the conditions in the field & contract engineering lump sum \\
2 & Man & poor competency of the engineering document maker & contract engineering lump sum \\
3 & Method & poor Engineering Document process & contract engineering lump sum \\
4 & Machine & the procedure for making engineering documents is not standard & contract engineering lump sum \\
5 & Environment & poor engineering document quality & company policy related to contractual preference \\
\hline \hline
\end{tabular}

TABLE 8.

PROCON ANALYSIS FOR PROPOSED IMPROVEMENT

\begin{tabular}{|c|c|c|c|c|c|c|}
\hline \multirow{2}{*}{ No. } & \multirow{2}{*}{ Proposed Improvement } & \multicolumn{2}{|c|}{ Control } & \multicolumn{2}{|c|}{ Impact } & \multirow{2}{*}{ Decision } \\
\hline & & Int. & Ext. & Significant & Insignificant & \\
\hline 1 & $\begin{array}{l}\text { The change in the contract model from lump sum becomes a volume } \\
\text { contract for a contract that is still ongoing }\end{array}$ & - & $\sqrt{ }$ & $\sqrt{ }$ & - & No \\
\hline 2 & $\begin{array}{l}\text { The company's preference for the form of the contract from lump sum } \\
\text { becomes a volume contract }\end{array}$ & $\sqrt{ }$ & - & $\sqrt{ }$ & - & Yes \\
\hline
\end{tabular}

From the Table 7, it can be concluded that the dominant root cause are the form of a lump sum engineering contract and company policy related to the preference for the form of the contract.

From Table 8 Pro-Con Analysis of Proposed Improvement below, one of the proposed improvent to changes the company's preference for the form of the contract from lump sum becomes a volume contract.

\section{E. Project Risk Management}

Project Risk Management is one of the tools used in determining the risk of waste. The following Table 9 is a list of risks identified based on critical waste RCA tables. After all risk had been identified then a risk assessment is carried out based on brainstorming with related experts in the company as shown in Table 10 and the result in Table 11 below. 
The $1^{\text {st }}$ International Conference on Business and Management of Technology (IConBMT)

August 3rd 2019, Institut Teknologi Sepuluh Nopember, Surabaya, Indonesia

TABLE 9.

PROJECT RISK REGISTER (SOURCE: BRAINSTORMING)

\begin{tabular}{cccc}
\hline \hline No & Categories & Sub-Categories & Risk \\
\hline 1 & PM & DED & Operational philosophy change \\
2 & PM & DED & Operational philosophy error \\
3 & PM & DED & Design calculation error \\
4 & PM & DED & Un-applicable design \\
5 & Engineering & Sub-Cons & Incompetence sub-contractor \\
6 & Procurement & Purchasing & Difficulty to get material / equipment \\
7 & Procurement & Delivering & damage or loss material / equipment \\
8 & Procurement & Delivering & delay arrived at location \\
9 & Procurement & Storage & damage or loss material / equipment \\
10 & Procurement & Storage & Poor storage location, times add \\
11 & Construction & Construction & Incompetence sub-contractor \\
12 & Construction & Construction & Work incident \\
13 & Construction & Construction & Lack of resources \\
14 & Construction & Construction & Work result under specification \\
15 & Environment & & Bad weather \\
16 & Environment & & Public security disruption \\
17 & Environment & & Government Act / policy \\
\hline \hline
\end{tabular}

TABLE 10.

RISK EVALUATION CRITERIA (SOURCE: BRAINSTORMING)

\begin{tabular}{|c|c|c|c|c|c|}
\hline $\mathbf{P}$ & Value & Description & $\mathbf{C}$ & Value & Description \\
\hline Rare & 1 & $0 \%<\mathrm{P} \leq 10 \%$ & Insignificant & 1 & No impact, meaningless financial loss \\
\hline Unlikely & 2 & $10 \%<\mathrm{P} \leq 30 \%$ & Minor & 2 & $\begin{array}{l}\text { need direct handling on the spot, financial losses } \\
\text { become overhead }\end{array}$ \\
\hline Moderate & 3 & $30 \%<\mathrm{P} \leq 50 \%$ & Moderate & 3 & $\begin{array}{l}\text { need to be handled by the planning manager, the loss is } \\
\text { quite significant }\end{array}$ \\
\hline Likely & 4 & $50 \%<\mathrm{P} \leq 80 \%$ & Major & 4 & $\begin{array}{l}\text { failure, productivity decreases, financial losses, need to } \\
\text { be handled by management }\end{array}$ \\
\hline Almost & 5 & $80 \%<\mathrm{P} \leq 100 \%$ & Catastrophic & 5 & $\begin{array}{l}\text { errors have an impact on other activities, need to be } \\
\text { handled by management leader, significant losses }\end{array}$ \\
\hline
\end{tabular}

TABLE 11.

RISK EVALUATION (SOURCE: BRAINSTORMING)

\begin{tabular}{llccc}
\hline \hline No & \multicolumn{1}{c}{ Risk } & P & C & Risk Value \\
\hline 1 & Operational philosophy change & 3 & 4 & 12 \\
2 & Operational philosophy error & 2 & 5 & 10 \\
3 & Design calculation error & 3 & 4 & 12 \\
4 & Un-applicable design & 3 & 4 & 12 \\
5 & Incompetence sub-contractor (Engineering) & 4 & 4 & 16 \\
6 & Difficulty to get material/equipment within deadline (Purchasing) & 3 & 3 & 9 \\
7 & Damage or loss material / equipment (Delivering) & 3 & 4 & 12 \\
8 & Delay arrived at location & 4 & 3 & 12 \\
9 & Damage or loss material / equipment & 3 & 4 & 12 \\
10 & Poor storage location, times add & 3 & 2 & 6 \\
11 & Incompetence sub-contractor (construction) & 4 & 4 & 16
\end{tabular}


The $1^{\text {st }}$ International Conference on Business and Management of Technology (IConBMT)

August 3rd 2019, Institut Teknologi Sepuluh Nopember, Surabaya, Indonesia

\begin{tabular}{llllc}
12 & Work incident & 2 & 4 & 8 \\
13 & Lack of resources & 4 & 4 & 16 \\
14 & Work result under specification & 4 & 4 & 16 \\
15 & Bad weather & 4 & 3 & 12 \\
16 & Public security disruption & 4 & 3 & 12 \\
17 & Government Act / policy & 1 & 4 & 4 \\
\hline \hline
\end{tabular}

\section{CONClusion, SugGestion, AND RECOMMENDATION}

\section{A. Conclusion}

Conclusions that can be drawn from this study are listed below:

1. The application of a lean construction approach is suitable to be applied in gas pipe installation projects, but with notes, because:

a. Only in engineering work that carried out by Company it's self.

b. The work executor changes according to the EPC auction winner.

c. Details of activity are specific to one project.

d. Every pipe installation area has their own difficulties and challenges, it's hard to be replicated.

2. The lean construction application approach are still necessary, because:

a. The quality of engineering work is classified as poor, amendment $<10 \%(12.81 \%)$.

b. Engineering work is a key to prevent waste at the next step (Proc. \& Cons.).

c. The company's role is very significant, determine wheather a design can go further upgraded to the construction stage or not.

d. Company already has an engineering function which actively continues to be involved in every project carried out by the company, therefore a pattern can be made based on previous improvements in the Standard Operating Procedure (SOP), TKO/TKI (Organizational Governance/Individual Governance)

3. The time needed to complete engineering task is exceeded the available time in PMS.

4. The dominant root cause is the lump sum engineering contract form.

B. Suggestion \& Recommendation for Company \& The Next Subsequent Research

1. Applied the lean construction approach in Company gas pipeline construction project in the engineering work section.

2. Needs a comprehensive evaluation of man power, load, skills needed and allocated time to complete the entire engineering document, because the time needed greater than the available time.
3. Needs to review the man power and the ideal times to complete each deliverables.

4. Needs to make clear standard and timeline to make and review of engineering documents along with the required engineer specifications.

5. Needs to make accompany acknowledged standard, related to engineering methods, specifications, cross disciplines workflows (mechanical, piping, civil, instrument, electrical).

6. Changes of the contract preference, from a lump sum contract to a volume engineering because a waste occurrence engineering works tends to stimulated waste occurrence at the next stage of the project, procurement and construction.

7. Conducts a review of the engineering documents that have been produced to see the possibility that it can be used in other projects.

8. For further research the application of lean construction is more suitable in the field of manufacture or in companies whose core business is conducting construction projects.

\section{REFERENCES}

[1] T. Ohno, Toyota Production System Beyond Large Scale Production. New York: CNC Press, 1988.

[2] H. Kerzner, Project Management: A System Approach to Planning, Scheduling and Controlling. Hoboken, New Jersey: John Wiley \& Sons, 2009.

[3] V. Gasperz, Lean Six Sigma for Manufacturing and Service Industries. Jakarta: PT. Gramedia Pustaka Utama, 2007.

[4] L. Koskela, G. Howell, G. Ballard, and I. Tommelein, "The Foundation of Lean Construction," in Design and Construction: Building in Value, R. Best and G. De Valence, Eds. Oxford, UK: Butterworth-Heinemann, Elsevier, 2004.

[5] L. Koskela and G. A. Howell, "The underlying theory of project management is obsolete," in $P M I \circledR$ Research Conference 2002. Frontiers of Project Management Research and Applications, 2002.

[6] L. Koskela, "Application of The New Production Philosophy to Construction," 1992.

[7] A. P. Dillon and S. Shingo, "A Study of the Toyota Production System: From an Industrial Engineering Viewpoint," 1989. 